\title{
The clinical method, model competence in the learning medical education
}

\author{
Miguel A. Galván-Morales ${ }^{1 *}$, Fidencio Mejía-Nepomuceno², and María E. Palomar-Morales ${ }^{3}$ \\ ${ }^{1}$ Department of Research of Immunogenetics and Allergy; ${ }^{2}$ Department of Smoking and Chronic Obstructive Pulmonary Disease (COPD); ${ }^{3}$ Gender \\ Unit. Instituto Nacional de Enfermedades Respiratorias "Ismael Cosio Villegas", Mexico City, Mexico
}

\begin{abstract}
Constant innovation occurs in medical education, as well as in any other professional and academic activity. There must be mastery of a methodology in the form of an academic discipline that constantly monitors and requires updates. However, the clinical method, despite its antiquity, still takes effect in the new wave of ways and systems to learn medicine (Problem-based learning, evidence-based medicine, and among other techniques). The different methodologies have not undergone the modification of the method. This is certainly due to two reasons, the requirement of a radical change in the nature of the medical staff and their perception of medicine, which requires a change in the epistemology of the medicine. We present a brief overview of the forays of pedagogy in medicine and clinical method as a non-static technique or discipline that evolves with changes in knowledge, which refers to data collection in an orderly manner, regarding the disease and that has proven to be an outstanding tool in meeting certain goals toward diagnosis, prognosis, and treatment.
\end{abstract}

Key words: Constructivism. Cognitivism. Proximal zone. Meaningful learning. Problem-based learning. Learning competences.

\section{Introduction}

The practice of medicine is enriched and changed by scientific contributions and technological innovations. Thus, it represents a constant growth of knowledge for human beings and especially regarding the binomial health-disease approach. Medicine is nurtured by other sciences whose advances result in a kind of dynamism that allows for expanding medical education, making it creative, conversing with other sciences, being receptive to the application of technologies, and benefitting from educational innovations ${ }^{1}$. Due to this growing dynamism, it is necessary to review the curricula of medical schools worldwide. To guide it to use different methods and techniques with the aim of facilitating learning through semantic networks ${ }^{2}$. Currently, the teaching of the medical sciences is immersed in analysis and debate processes, which is different from past trends. Nowadays, the traditional education methods based on classes and conferences have incorporated other educational processes such as problem-based learning, teaching procedures using simulators, competencies, databases, medicine based on evidence, and meaningful learning. All with the purpose of preparing the student to master the discipline. Because of the importance of such a practice, it is necessary to incorporate elements that reinforce medical education. Therefore, this text is aimed at explaining it. The main approaches, methods, and strategies in medical education cannot displace the clinical method, but it must promote and strengthen its development and usefulness. By analyzing the importance of learning in

\section{Correspondence:}

*Miguel A. Galván-Morales

E-mail: ygalvan2000@yahoo.com.mx NC-ND license (http://creativecommons.org/licenses/by-nc-nd/4.0/)
Available online: $21-04-2020$

Rev Med Hosp Gen Mex. 2020;83(2):88-96 www.hospitalgeneral.mx 
the preparation of the clinical record through the clinical method during medical training, making a correct diagnosis with the correct preparation and incorporating it into the competency of any doctor for their practice. Hence, some aspects are described in the method that is relevant and decisive. Finally, some of the concrete ways in which the competencies for doctors can be reinforced will be described, prioritizing those related to clinical judgment, which is the core of this professional activity. In this way, addressing the main approaches, methods, and strategies cannot displace the clinical method and nevertheless should promote and strengthen its development and usefulness.

\section{The teaching of medicine}

Empirical forms began with the appearance of the human being as a society, as demonstrated by Marc Armand Ruffer, who described what was achieved by the Mesopotamian and Egyptian cultures in the papyri that dated back to $4000 \mathrm{BC}$. Conversely, he highlighted the Hindu, Hebrew and Chinese medicine, with records that range from the $26^{\text {th }}$ century $B C$ to the $2^{\text {nd }}$ century $A D^{3}$. Subsequently, medicine in classical Greece Hippocrates and his work with the 50 Corpus Treaties Hippocratic, the Cyrene medical schools $\left(4^{\text {th }}\right.$ and $3^{\text {rd }}$ centuries BC), Rhodes, Cnidus, Croton, Alcmaeon, Pergamon, as well as the school of Alexandria by Herophilus, Erasistratus, and Galen ${ }^{4}$ on the part of the Greco-Roman era, Galen of Pergamon (129-216 AD). Later in the Byzantine Empire, hospitals were used for teaching medicine as well as during the Islamic Golden Age. In the middle ages, the first secular medieval center of medicine was Salerno, the Medical Schools had two or three chairs, called Prima, Vespers, and Meth$\mathrm{od}^{5}$. In Europe and North America, pedagogical ideas incorporated into aspects of scientific thinking were used $^{6}$. Ultimately, educational technology appeared, which sought to serve large groups through the systematization of education, based on the systems theory, the utilization of means of communication and behaviorism. Therefore, systematized learning methods and techniques were emphasized. This current of behaviorists focused on observable behavior, disregarded all internal learning processes, and learning was centered on the attainment of minimalist and highly specific objectives $^{7}$. The cognitive approach, which makes a functional analogy between the mind and the computer that are analyzed as processing systems that encode, retain and operate with internal symbols and representations $^{8}$. Constructivism appears in 1926 with Jean
Piaget and Lev Vygotsky, but is still in force today, was initially grouped into cognitivism and then separated by its characteristics, where human knowledge was not received passively, from the world or anyone else, which was not discovered either, but was processed actively built by the subject who knows (knowledge). This ideology has four principles: (1) it was based on the conceptual structure of each student, based on the ideas and preconceptions that the student had on the subject; (2) it predicted the conceptual change expected from the active construction of the new concept and its impact on the mental structure; (3) it confronted the ideas and preconceptions related to teaching, with the new scientific concept that was taught; and (4) it applied the new knowledge to actual situations, relating it to other concepts within the cognitive structure, to expand the scope of its transfer. Thus, it was possible to generate arguments that motivated self-criticism and was able to apply new knowledge to real situations, by relating and integrating not only information but also habits and values, which are characteristic of the human essence ${ }^{9}$.

\section{Paradigms of education and learning according to flexner and constructivism}

The first major medical education reform occurred in North America at the beginning of the $20^{\text {th }}$ century, when Abraham Flexner conducted a study and wrote a report for the Carnegie Foundation on medical schools in the United States and Canada. The information obtained by Flexner led to a change in medical education and made important changes in the medical curricula, permeating it with the objectives of medical education, the organization in two teaching cycles: basic and clinical, as well as the order and sequence of subjects, plus the selection of applicants and methodological design. According to Flexner, three methods can be used: the didactic method (lectures), demonstration lessons and practice, issues that were previously absent in the medical training in the United States ${ }^{10,11}$. The emphasis of this author was aimed toward making an adequate selection of the candidates for this profession. Then, teaching had to be organized in such a way that diseases, organs, and systems were easily understood. In this way, at later stage students could move on to learning and clinical practice ${ }^{12}$. Although this reform meant a breakthrough in medical training per se, the teacher had a huge pre-eminence over the student. Likewise, the basic/clinical level scheme established a cut between theory and practice, where it was first 
necessary to understand the theory and study procedures to apply them to actual cases subsequently. A second transformation in the teaching of medicine is the constructivist-cognitive conception of learning, as well as the communicative and technological expan$\operatorname{sion}^{13}$. This important transformation that occurred in medical education has many versions: the Piagetian, Vigotsky, Ausubel of the 70s, Bruner of the 90s, the Spanish version of César Coll et al., the Argentinian of the epistemological conflict of Castorina, and many others. As well as, the Mexican represented by Emilia Ferreira and Rolando García, and the cognitivism of Frida Díaz Barriga ${ }^{14}$. The constructivist paradigm derived mainly from the studies of Jean Piaget and Lev Semionivich Vigotsky, who conceived the apprentice as an active subject, whose job was not to absorb the teacher's knowledge and technical ability, but to build their own (own), evolving through a continuous transformation of their thinking and action schemes toward a greater intellectual and practical ability, whose motor is their action on the object they intend to know. For Piaget (1973), knowledge was possible only if the apprentice acted on the objects of knowledge, either on a physical action (especially in the $1^{\text {st }}$ years of life), or through a logical-mathematical conception, by means of the operations organized in a successive chain of stages (formed during the school years) and in a long process that enables it to have a scientific thought. Vigotsky was also interested in the constructive processes of human thought and based on studies carried out by Kohler and other Soviet researchers, on the use of tools by superior hominids, while influenced by his fascination with literature and art (the world of signs and symbols) formulated a theory according to which, human beings learn to act collectively in their social environment. The word and other symbolic and practical tools enabled them to bring the knowledge that surrounds them inside to think and act therewith. It was Vygotsky who coined the concept of the Zone of Proximal Development (ZPD), defined as the distance between what someone can do alone and what they can do when helped by others. The ZPD is a social space in which "the intentions, the products of those involved in a teaching-learning process or more widely of cultural appropriation are exchanged"15. The importance of the ZPD lay in that only by identifying them; one can help another to learn and thus teach, in this paradigm is to help learn, while learning is to interact physically and intellectually with the learning objects. These approaches are in the other Flexnerian pole, which gives greater emphasis to the teaching control in the didactic and organizational environment, and not in terms of the construction of the subject, because he was clear that the one who was trained was the student itself. Jerome Bruner, supporter and central axis of the constructivist theory, proposed a collective education process connoted by the collaboration, dialogue, and agency of all participants in the common work. In addition, he promoted the exchange of knowledge among students and the analysis of the shared senses, both of the teacher and others in the ZPD of their peers in the educational activity, or "class." Moreover, his main theory was known as discovery learning. The main feature of this theory is that it promotes the student to acquire knowledge for itself ${ }^{16}$. Bruner collaborated with David Paul Ausubel in the 70s (1973), who contributed with learning by reception and learning by discovery in its studies, as well as concepts of meaningful learning, still in force in medical education. This is a type of learning that relates the new information with what is already acquired, readjusting, and reconstructing both information, that is, what is recently acquired as ideas, concepts, and propositions are connected with a relevant concept already existing in the cognitive structure ${ }^{17,18}$. Although the debate continues among scholars of these authors, they all have in common that the student is not a recipient of the information provided by the teacher, but a re-constructor of the knowledge proposed in the formal curricula. The teacher is support that, together with their peers, acts as mediators or leaders in their learning. From this outlook, the reception of knowledge followed by its application and the repetitive learning of concepts is displaced by dialogic learning, aided by the elaboration of schemes, experimentation, research, and search. Debates, dialogs, case studies, Problem-Based Learning, and the use of simulators enrich student learning and promote the diversification of the teaching job ${ }^{19}$.

\section{Medical education by competencies}

There are currently other proposals on education and human learning. Such is the case of competency education, which is defined as the ability to select and acquire knowledge, skills, and attitudes to respond successfully to a given situation. The educational model for integrated competencies for education is an option that seeks to generate higher quality training processes, without losing sight of the needs of society, the profession, the discipline process, and academic responsibility, meaning that all of this is a more dynamic approach to the reality of those who develop each task. In other words, the concept 
of competencies harmonizes knowledge with expertise, where "Knowledge," mastery of theoretical and practical knowledge, "Expertise," the acquisition of skills, abilities, and procedures that when combined, guarantee productivity, "Knowing how to be," generates the development of personal attitudes, norms, and values ${ }^{4,20}$.

Competency education is really an approach that considers the social sphere as a privileged destination of its efforts and performance of each individual that it trains. It is the social and, above all, the working sphere, which is expected to train professionals who are capable of solving labor problems, simultaneously training participatory citizens and social subjects capable of living with others and being decisive in all schemes. In this environment, these social expectations are one of the great references for university education. According to the document, Development and Selection of Competencies for Latin America, the education by competencies has as reference an active subject, director and builder of its own knowledge, for life, capable of solving the ethical, citizen, and professional problems that are continuously presented, while being responsible for the decisions made, since its learning comes from someone dedicated to what is taught ${ }^{21,22}$. Among the various versions of this approach to competency education are those that also link it to complex thinking, according to Tobón, 2007.

In the case of the physician, competency education has an approach with new challenges to train professionals who have the ability to solve health problems, performing professionally as whole subjects who know, know how to do (what they know), and they act with relevance in their social context, in front of a subject (human being) who has a life, an identity, gender, age, culture and is not just a disease. In this sense, competency education exceeds (at least in its explanation), the Flexnerian perspective, now judged as training that privileges the study of the diseases, leaving the patient in the background. With what has been described above and applying the competency model, it is intended that the physician acquires the ability to transmit knowledge in an integral way through a tool called a clinical method, a set of knowledge and skills that will allow an accurate diagnosis to be established ${ }^{23}$.

\section{Clinical method}

The clinical method is the orderly process or sequence of actions that doctors have developed to generate their knowledge since the beginning of the scientific era. The scientific method applied to clinical practice is the order to study and understand the health-disease process of a subject in all its social, biological, and psychological integrity. By applying the clinical method, medical knowledge that has a historical-social connotation is being developed and constructed, since the process of knowing depends on the time and space in which a society develops. In this way, within each society, diverse knowledge is developed about all aspects that concern man ${ }^{24}$. Its golden age was in the second half of the $19^{\text {th }}$ century, after an important void since the socalled Hippocratic clinic. For the Greeks, the clinical observation was the basis of medical practice that once properly performed, should allow for the collection of all the symptoms, signs, and changes in the patient's condition during the course of its illness. In this way, proper clinical practice led to: (1) a successful diagnosis; how did the patient differ from normal? (2) an appropriate prognosis, which was made by comparing with other patients with similar conditions, and (3) an appropriate treatment that depended on the certainty of the prognosis in other patients. The clinical method makes the medical clinic scientific, becoming a perfectible method, which retained and improved the techniques used for medical diagnosis ${ }^{25}$. The process of diagnosis or method of diagnosis is a process or mental method by which doctors gain an understanding of the disease, by interpreting its clinical manifestations. It is a scientific method applied to medical practice that was created and remains linked to phenomenological medical science that corresponds to a human medical practice. With the establishment of the clinico-anatomical correlation method, then surpassed by the clinical method is believed to have reached the method of explanatory scientific medicine ${ }^{26}$. Currently, clinical medicine continues to be a human practice that is carried out based on a scientific method: the diagnostic process or diagnostic method. Biomedical and clinical explanatory medicine has its method, the experimental method. It is thought that for this reason the denomination of "clinical method" has been losing validity in the present. Therefore, when it is said whether the clinical method exists, it is understood, according to the denomination used, that medical practice has always had and continues to have its scientific method: the method of the diagnostic process, however, it can also be used as equivalent of the clinical method ${ }^{27}$.

\section{Analysis of the clinical method}

The clinical method can be analyzed, from the objective defined by studying and understanding the health and/or disease process of a patient. Immersed 
in a problem that leads to its consultation, which implies arriving at the medical diagnosis (knowing), establishing a prognosis (getting ahead in time) according to the natural history of the disease or also of the clinical horizon and devising a treatment to resolve the situation. In summary, the aspects contemplated by the clinical method include three elements: diagnosis, prognosis, and recommendations ${ }^{28}$.

\section{Diagnosis}

Diagnosis is understood as the set of signs and symptoms that serve to fix the peculiar nature of a disease and it is also the qualification that the doctor gives to it according to the clinical picture, which the clinician warns and that also uses propedeutics and semiology; which is the orderly grouping of methods and procedures that the doctor uses to identify the symptoms and signs present in the patients and with them elaborate the "diagnosis," which includes the history and physical examination ${ }^{27}$. The semiology refers to the study of signs in patients to identify alterations caused by diseases. The diagnosis is then an inferential process, made from a clinical picture, designed to define the disease that affects a patient. When talking about a clinical picture, there are three interrelated elements: the syndrome or set of symptoms and signs that the patient presents as a result of the disease; the disease and the context, which is the social, economic, and psychological environment in which the subject suffering from the disease is located ${ }^{29}$.

\section{Diagnostic elements}

It is difficult to define what steps must be followed to reach a correct diagnosis. Most of the time, it is an intuitive process of which its components are not explained. When analyzing what elements compose it, the following can be mentioned: generation of diagnostic hypotheses, refinement of diagnostic hypotheses, and verification of diagnosis.

\section{Generation of diagnostic hypotheses}

During the consultation with the patient, diagnostic hypotheses are constantly generated. They will define the space in which the actions that will lead to the final diagnosis will be framed. Various methods have been described by which doctors generate hypotheses. One of them is the Gestalt approach to diagnosis, in which, by observing the elements or parts constituted by the symptoms or signs, the doctor intuitively forms a mental image of what may be happening with the patient, the whole ${ }^{30}$. Another approach described is the use of heuristics to generate hypotheses and assign them a probability of occurring. It consists of the unconscious, non-rigorous methods that simplify the complex processes necessary to reach a solution in a situation of uncertainty; they are a kind of shortcut, initially described by the cognitive sciences ${ }^{27,31}$. It is a subjective way of assigning probability. Three heuristic principles used to estimate probability have been described: (1) representativeness; it is used when estimating the probabilities considering how representative element $A$ of category $B$ is. For example, if a patient has the typical symptoms and signs of a stroke, it is a representative element of the category of patients with cerebrovascular accidents and is assigned a high probability that it actually has one. (2) Availability, the probability is estimated by the ease with which a given picture can be evoked. It is a useful approximation since large or very frequent categories can be evoked very easily. For example, when a doctor examines a patient with polyphagia, polydipsia, and polyuria, the doctor will quickly evoke the diagnosis of diabetes mellitus, as it is much easier to evoke such a cause than, for example, psychogenic polydipsia. (3) Anchorage and adjustment; an initial probability, called an anchor, is estimated, which is subsequently adjusted according to new information found. A final method to generate diagnostic hypotheses is that of the previous probability or prevalence of the condition. Thus, the doctor who examines a patient because of a headache could immediately make a list of the most prevalent diagnoses among the patients who consult for that reason in their workplace, which will be their initial diagnostic hypotheses. This prior probability is called the pre-test probability that derives from the set of symptoms, signs, or exams analyzed in the first instance. Subsequently, the test is given, a term that refers to describe the new information, whether symptoms, signs, or additional tests, which have not been incorporated in the first instance. Finally, the post-test probability, which is the new probability modified by the test ${ }^{29,31}$.

\section{Refinement of diagnostic hypotheses}

Incorporating new information. This is the second stage in the diagnostic process, after raising the first hypotheses. In its new pieces of information on the clinical history, physical examination and additional exams are added that will allow to discriminate between 
the different hypotheses generated in the previous stage. The diagnostic process is not sequential or unidirectional, but we will constantly be evoking new hypotheses and eliminating others, as more information is available. One way to gather information is to systematically search for symptoms, whether or not they have to do with the mental representation of the hypothesis in question. Another example of this approach is routine laboratory tests. Another form of compilation is the comparison of the current case with the idea that the clinician has of the suspected picture. A key element in this stage is the mental representation of the different diagnostic hypotheses ${ }^{32,33}$. In addition, the genetic diagnosis of diseases of this origin that includes inherited, congenital and alterations in the genetic material should be considered. The procedure consists of analyzing DNA sequence variants associated with a disease. Actions include the stages of preconception and during the life of the individual, and intergenerational monitoring. The genetic diagnosis includes pathogenic mutations and sequence variants that cause disease, which is usually found at a frequency of less than $1 \%$ in the entire population. They are called polymorphisms or neutral variants to the sequence variants that per se are not pathogenic and are present in a frequency greater than $1 \%$ in the population. Through the Human Genome Project completed at the beginning of this century, a better approach to diseases is allowed through the progressive development of diagnostic tools, preventive measures, and more slowly therapeutic strategies. In this age, there is increasing progress of epigenetics in the regulation of gene expression and the origin of the disease that has given rise to the Human Epigenome Project*.

\section{Diagnostic verification}

How to decide on what behavior to take? How to deal with uncertainty? Each time an additional test is applied, it is done for one of two reasons: because it is considered necessary to increase the probability of the diagnosis to a sufficiently high level, in which the concordant treatment is considered, or because it is necessary to carry the probability at a sufficiently low level to rule out the diagnosis ${ }^{34}$. These levels of certainty, both to confirm and to rule out a diagnosis, are called decision thresholds. Above this point, it is no longer necessary to carry out new tests, if not to start the diagnosis, this procedure is defined as a therapeutic threshold. The one below which, the new test is no longer required because it is estimated that the probability is so low that it is not justified is called the additional study threshold or the diagnostic threshold. These decision thresholds are not fixed for all diseases or for all patients, which will determine if the thresholds are higher or lower. The cost will depend on them, and in this case, the term cost refers to something much broader than the monetary cost. It includes the costs of passing an important diagnosis; to treat a healthy patient or with a different disease, with a potentially toxic therapy; of the risks of the test; of patient values and preferences. "Sans erreur de semiologie, il n'y aurait presque jamais d'erreur de diagnostic" (Babinski) (Without semiology error, there would almost never be a diagnostic error). According to the above, it can be mentioned that the diagnosis is based on the analysis of safe data. The reasoning will only be valid when it rests on exact notions and precise facts, where the validity of a deduction depends on the quality of the observations on which it is based ${ }^{35}$. Considering these principles, it is essential to present some basic premises on which the medical diagnosis is based; these are the doctor-patient relationship and communication, the history, physical examination, and diagnostic tests $^{36}$.

\section{Doctor-patient relationship and communication}

To obtain medical history, the doctor has a special form of communication. At the beginning of the doctor-patient relationship, the doctor must gain the patient's trust, the doctor must ensure that the patient feels comfortable and speaks freely, generate some comments that suggest affinity and that the patient perceives that what the doctor intends to help it. It is important to observe the patient's body language; the patient's attitude is a valuable key to discover or interpret the patient's ailments. In addition to the attitude, gestures, and expression, the doctor must convince the patient that it is devoting all its attention and that it will not be surprised or impressed by anything it can say. When it is time for physical examination, gentleness is very important, for example, to perform abdominal palpation must be simultaneously firm, gentle, and warm ${ }^{37}$.

History: It is the term used to name the knowledge and skills with which the doctor identifies the signs and symptoms (clinical semiology), and to refer to the information provided to the doctor by the patient during a clinical interview, to incorporate such information to the medical record. It is fundamental for the diagnosis to know the problems and personally identify the individual and obtain 
a retrospective of the patient and determine the relevant family, environmental, and personal elements ${ }^{38}$.

The diagnosis or clinical procedure is then the procedure by which disease, nosological entity, syndrome, or any health condition and disease is identified. In terms of medical practice, the diagnosis is a clinical judgment about the psychophysical state of a person. It represents a manifestation in response to a demand to determine such status and the alterations or agents that promote it and that are identified by the clinical laboratory, the latter essential tool for making the diagnosis. Laboratory and cabinet tests help determine a diagnosis, plan, and control if the treatment is effective, or monitor the disease over time. Occasionally, the one defines the prognostic diagnosis and treatment ${ }^{39}$. Therefore, to diagnose is to name the patient's suffering; it is to give it a "tag" 40 . There are several types of diagnoses such as clinical or individual diagnosis, diagnostic signs, and etiological diagnosis. In addition, another of the important tasks of the doctor is to define the prognostic task as a prediction of the future course of a disease after its onset. Because the doctor must rely on the natural history of the disease to define, where the patient is and give certainty to the forecast. The term refers to the possible outcomes of a disease and the frequency in which it can occur. However, knowledge and identification of a given prognosis should contribute to the establishment of preventive practices that modify the course of the disease ${ }^{41}$. Predicting the future is a difficult task if there are no elements of support beyond common sense and chance. One way to minimize uncertainty about the future of disease suggests generating an estimate based on the following elements: clinical experience, epidemiological information, and statistical probability and the clinical horizon of the disease. Such elements allow predicting the future as precisely as possible. The clinical experience, although valuable, is the most limited for making prognostic decisions because it is based on a more or less limited set of patients who are usually not representative of all of them. In addition, it can lead to an unequal follow-up in its conditions, presenting patient selection bias, information bias, and lack of casuistic precision. The statistical probability is the tool par excellence for the prognostic exercise because it allows estimates to be made regarding the various forms of evolution of a disease with well-defined precision margins ${ }^{42}$. However, the natural history of the disease puts us in the place where the patient can be found, and finally, the possibility of healing. The prognosis will then depend on the natural history of the disease and its clinical course, on the correct description and on the recognition and control of biases that affect said description, either by design or through research analysis in a simultaneous and complementary manner ${ }^{43}$.

\section{Educational aspects of the clinical method}

Among the possibilities of teaching medicine and through the clinical method, promoting the achievement of competence to perform clinical reasoning and understanding the importance of knowing how to prepare, interpret, and use the clinical file, the following can be mentioned:

1. The class or lecture. In it, the expert clearly emphasizes facts, guides the analysis, shares experiences, and shows how this reasoning is done; it can involve students in the interpretation of cases and clinical experiences.

2. The investigation of topics by students and their presentation to the group. A widespread practice, at least in the hospital environment. Resident doctors study subjects, explain cases by teaching other resident physicians while still learning as that phrase says: teaching is learning twice.

3. Evidence-based medicine: Knowing this strategy, knowing how to prepare the question and investigating research with a high degree of methodological rigor can contribute to the training physician confirming their assertions, testing them, confronting them with the investigation of similar cases, from which they can learn ${ }^{44}$.

4. Problem-based learning: By following a structure for reviewing cases in which one must participate by posing hypotheses, seeking answers, and incorporating data, one can favor the fact that a fact is linked to another, the process of analysis that must be made of the semiology, heredofamilial antecedents of the patient, is understood, the explanation of relevant data, etc., which will allow the group of students to dialog with each other developing skills for collaborative and communicative work ${ }^{45}$.

5. Review of cases and clinical records: Work with the training doctor, or the associate doctor. Listening to the analysis of clinical cases will strengthen the doctor's awareness in deepening in each of the aspects involved in them and which it can learn from others ${ }^{46}$.

6. Meaningful learning, or the learning of medical procedures before real, simulated, and standardized 
patients, with whom these procedures are performed daily. With a previous preparation or equipped with a work guide, the student can be taken to situations in which it can practice procedures that require precision and learn sequences of standardized actions with the programmed simulators. One practices questioning or the observation of symptoms and signs of the patient without running greater risks than it may face. This can also mean visiting real patients and always taking care of patient's safety, without subjecting them to mere learning objects ${ }^{47}$.

The quality of the record of medical care is found in the clinical record, as well as the process of medical evolution as a history, where all of his background transits, as well as the studies were done throughout his care in some hospital center. The Official Mexican Standard NOM-168-SSA1-1998, of the Clinical File, establishes the mandatory scientific, technological, and administrative criteria in the preparation, integration, use, and archiving of the clinical file, being a medical-legal document. The doctor, the nurse, and the administrative staff that handle and insert information must know the ranges of dispositions so as not to commit an illicit or harm to the patient and the norm. Because section 4.4 says: that the clinical file is the set of written, graphic, and imaging documents or of any other type, in which the health personnel must make the records, notes, and certifications corresponding to their intervention, according to sanitary provisions. It must comply with content and reservation guidelines that will only be used exclusively by health personnel and in accordance with the procedures and guidelines of the standard. Therefore, it is necessary for the student to give all the necessary information on the management of the clinical record ${ }^{48}$.

\section{Conclusion}

Medicine in some of their practices has been of total innovation, so many of its methodological and teaching aspects have been modified. In its evolution, it has allowed us to see the horizon through which he has traveled and which medical practice have remained immovable. Teaching medicine has been produced within universities and through principle-based schemes around the world. Non-medical application were postulated by Vygotsky with the concept of the ZPD, and applied to this one, beating Flexner. The way medicine is taught at its core has maintained the most constant transformation in the description of pathologies, the functioning of the systems, the organism and how to predict the evolution of the disease. How and when to refine the diagnosis and how treatment evolves and is applied. Skills have made medicine develop an area of knowledge and experience. Although this practice was already old, it was lost in the division of basic and clinical cycles and has been recently recovered. The clinical method, however, is a discipline that has not changed and that leads the doctor to an accurate diagnosis, even with technology. We believe that this practice in teaching achilles heel and must be stimulated for the doctor to understand the mental process and know of its importance.

\section{Conflicts of interest}

The authors declare that there are no conflicts of interest between the authors and anyone else. This manuscript is a collective work arising from the joint effort of its authors. It has not been published or submitted, in whole or in part, for review to another journal in print or electronic format.

\section{Ethical disclosures}

Protection of human and animal subjects. The authors declare that no experiments were performed on humans or animals for this study.

Confidentiality of data. The authors declare that no patient data appear in this article.

Right to privacy and informed consent. The authors declare that no patient data appear in this article.

\section{References}

1. Soberon AG. La Educación Médica en México. El Colegio Nacional; 2003. http://www.colegionacional.org.mx/SACSCMS/xstatic/colegionacional/template/pdf/2003/35

2. Perkins D. El Aprendizaje Pleno: principios de la Enseñanza Para Transformar la Educación. 1ª ed. Buenos Aires: Paidós; 2010. p. 292.

3. Depaolo C. Sir Marc Armand Ruffer, MD: The early years, 1878-1896. J Med Biogr. 2019;3. doi:10.1177/0967772019883998.

4. Zerquera TR, Rodríguez JV. Breves fundamentos históricos de la enseñanza de la Medicina en el mundo y en Cuba. Cuad Educ Desarro. 2011;3:30. http://www.eumed.net/rev/ced/30/ztrj.pdf.

5. Longrigg J. Greek Medicine: from the Heroic to the Hellenistic Age a Source Book. $1^{\text {st }}$ ed. Abingdon, United Kingdom: Routledge; 1998. p. 1-233.

6. Huapaya YJ, Lizaraso CF. Educación médica: nuevos paradigmas. Modelo educativo por competencias. Rev Horiz Med. 2011;11:86-92. Available from: http://www.medicina.usmp.edu.pe/horizonte/2011 II/Art5 Vol11_N2.pdf.

7. Escamilla de los Santos JG. Selección y uso de la Tecnología Educativa. México; Trillas; 2000. p. 26-51.

8. Henson KT, Eller BF. Psicología Educativa Para la Enseñanza Eficaz. México: Thompson; 1999. p. 242-69.

9. Ochoa RF. Hacia una Pedagogía del Conocimiento. Colombia: Mcgraw Hill; 1994. p. 234-44

10. Flexner A. Medical education in the United States and Canada. From the carnegie foundation for the advancement of teaching, Bulletin number four, 1910. Bull World Health Organ. 2002;80:594-602.

11. Piñero JM. Breve Historia de la Medicina. $1^{\text {a }}$ ed. Madrid: Alianza Editorial; 2000 
12. Piñero JM. Medicina, Historia y Sociedad. Antología de Clásicos Médicos. Barcelona: Ariel; 1973. p. 351-74.

13. Scott JC. The mission of the university: medieval to postmodern transformations. J Hig Educ. 2006;77:1-6.

14. Task Force on Health Systems Research. Informed choices for attaining the Millennium Development Goals: towards an international cooperative agenda for health systems research. Lancet. 2004;364:997-1003.

15. Wertsch JV. Vygotsky y la Formación Social de la Mente. $1^{\text {a }}$ ed. Barcelona: Paidós, Aires; 1988. p. 264.

16. Bruner JS. Desarrollo Cognitivo y Educación. Madrid: Ediciones Morata. $2^{a}$ ed. 1995. p. 1-16.

17. Ausubel DP, Novak JY, Hanesian H. Psicología Educativa: un Punto de Vista Cognoscitivo. $2^{a}$ ed. México: Trillas; 2000.

18. Romero AM, Quesada AA. Nuevas tecnologías y aprendizaje significativo de las ciencias. Enseñanza Cienc. 2014;32:101-15.

19. Erasmo ZC, Rodríguez YB. Algunas Consideraciones Sobre el Concep to de Zona de Desarrollo Potencial. Available from: http://www.rieoei.org/ deloslectores/1668carrillo.pdf.

20. González J, Wagenaar R, Beneitone P, editors. Tuning America Latina: un proyecto de las universidades. Rev Iberoam Educ. 2004;35:18-54.

21. OCDE. La Definición y Selección de Competencias Clave: Resumen Ejecutivo; 2005. Available from: http://www.deseco.admin.ch/bfs/deseco/ en/index/02.parsys.43469.downloadlist.2296.downloadfile.tmp.

22. Beneitone y Otros. Reflexiones y Perspectivas de la Educación Superior en América Latina. Informe Final América Latina 2004-2007. España: Universidades de Deusto y Groningen; 2007.

23. García M, Morillas L. La Planificación de evaluación de competencias en Educación Superior. Fac Educ Univ Murcia. 2011;14:113-24.

24. Sergio T. El Enfoque Complejo de las Competencias y el Diseño Curricular pro Ciclos Propedéuticos. En: Revista Acción Pedagógica Número 16, Enero-Diciembre; 2007.

25. Ilizástigui FD. El método clínico: muerte y resurrección. Rev Cubana Educ Med Super. 2000;14:109-27.

26. Shuter P, Rees B. Medicine Through Time. Oxford: Heinemann; 1996 p. 476 .

27. Rodríguez AC, Atocha A, Arauz A. Medicina y Lógica: el Proceso Diagnóstico en Neurología. Ludus Vitalis. 2008;16(30):136-63.

28. Alberto JM. Algunas aplicaciones sobre el Método Clínico. Fundacion 2004;12:23-5. http://www.villavicencio.org.ar/pdf/023\%20algunas\%20 apreciaciones\%20sobre\%20el\%20metodo\%20clinico.pdf.
29. Mcwhinney IR. Are on the brink of a major transformation of clinical method? CMAJ. 1986;135:873-8.

30. Tversky A, Kahneman D. Judgement under uncertainty: heuristics and biases. Science. 1974:185:1124-31.

31. Mézquita JF. El arte del diagnóstico. Med Int Mex. 2006;22:246-52.

32. Kassirer JP, Kopelman R. Refinement of diagnostic hypotheses. In: Learning Clinical Reasoning. Philadelphia, PA: Lippincott Williams and Wilkins; 1991. p. 11-7.

33. Capurro D, Rada G. El proceso diagnóstico. Rev Méd Chile. 2007;135:534-8.

34. Ars E. Métodos de diagnóstico genético de las enfermedades renales hereditarias. Nefrología. 2011;2:1-19.

35. Murphy E. The diagnostic process. En: The Logic of Medicine. Baltimore: The Johns Hopkins University Press; 1997. p. 281-314.

36. Harrison BE. Principios de Medicina Interna. $20^{\mathrm{a}}$ ed., Vol. 1. Madrid: Mc Graw-Hill; 2019. p. 1-14.

37. El diagnostico LE. Médico Historia y Teoría. $1^{\mathrm{a}}$ ed. España: Salvat Editores; 1982.

38. Surós J. Semiología Médica y Técnica Exploratoria. $5^{\mathrm{a}}$ ed. España: Salvat; 1977. p. 12-35.

39. Rodríguez PL, Rodríguez L. Principios Técnicos para realizar la anamnesis en el paciente adulto. Rev Cubana Med Gen Integr. 1999:15:409-14

40. García SM. El laboratorio, piedra angular en el diagnóstico médico. Bioquímica. 2006;31:3-5.

41. Díaz NJ, Gallego MB, González LA. El diagnóstico médico: bases y procedimientos. Rev Cubana Med Gen Integr. 2006;22:1-9.

42. Pita FS, Valdés CF. Determinación de factores pronósticos. Cad Aten Primaria. 1997;4:26-9.

43. de Dios JG, Pradas VI, Alapont VM. Evaluación de artículos científicos sobre pronóstico. Evid Pediatr. 2007;3:81.

44. Díaz NJ, Gallego MB. El pronóstico. Rev Cubana Med Gen Integr. 2004;20:2125.

45. Rappaport H. Consistency in prescription writing. An Intern Med. 1992;117:1059.

46. Sackett DL, Richardson WS, Rosenberg W, Haynes RB. Medicina basada en la evidencia. Cómo ejercer y enseñar la MBE. Madrid: Churchill Livingstone; 1997. p. 18.

47. Morales BP, Landa FV. Aprendizaje basado en problemas. Theoria. 2004;13:145-57.

48. Tarazona JL. Reflexiones acerca del aprendizaje basado en problemas. Una alternativa en la educación médica. Rev Col Obs Gin. 2005;56:147-54. 